\title{
A novel retinoic acid analog, 4-amino-2-trifluoromethyl-phenyl retinate, inhibits gastric cancer cell growth
}

\author{
KONG-WANG HU ${ }^{1,5}$, XIAO-HUA PAN ${ }^{2}$, FEI-HU CHEN ${ }^{5}$, RONG QIN $^{3}$, LI-MING WU ${ }^{4}$, HUA-GANG ZHU ${ }^{1}$, \\ FAN-RONG WU ${ }^{5}$, JIN-FANG GE ${ }^{5}$, WEN-XIU HAN ${ }^{1}$, CHUN-LIN YIN $^{1}$ and HONG-JUN LI ${ }^{1}$ \\ Departments of ${ }^{1}$ General Surgery, ${ }^{2}$ Gynaecology and Obstetrics, ${ }^{3}$ Pathology and ${ }^{4}$ Radiotherapy, \\ The First Hospital of Anhui Medical University, Hefei, Anhui 230022; \\ ${ }^{5}$ School of Pharmacy, Anhui Medical University, Hefei, Anhui 230032, P.R. China
}

Received July 31, 2013; Accepted October 31, 2013

DOI: $10.3892 / \mathrm{ijmm} .2013 .1574$

\begin{abstract}
Retinoic acid (RA) analogs have been used in the treatment of a variety of cancers; however, their application is limited due to serious therapy-related sequelae. In the present study, the effects of a novel RA analog, 4-amino-2-trifluoromethyl-phenyl retinate (ATPR), on the growth of gastric cancer cells were evaluated. Three gastric cancer cell lines, AGS, MKN-74 and SC-M1, were treated with either all-trans retinoic acid (ATRA) or ATPR, and their growth and distribution in different cell cycle phases were assessed using an MTT assay and propidium iodide (PI) staining followed by flow cytometry. The binding affinity of ATPR to the retinoic acid receptors, retinoic acid receptor- $\alpha$ (RAR- $\alpha$ ) and retinoid X receptor- $\alpha(\operatorname{RXR}-\alpha)$, was determined using ligand-binding assays. Activator protein-1 (AP-1) activity was measured using a luciferase reporter assay. Western blot analysis was used to determine cyclin E, Bcl-2 and Bax protein expression. ATPR preferentially bound RXR- $\alpha$ (0.04 nM) as compared with RAR- $\alpha$ (20.96 nM). Although both ATRA and ATPR inhibited the growth of AGS, MKN-74 and SC-M1 cells in a dose-dependent manner, a significantly greater inhibitory effect was observed with treatment with 5 and $500 \mu \mathrm{M}$ ATPR for 3 days $(\mathrm{P}<0.05)$. In addition, ATPR $(50 \mu \mathrm{M})$, but not ATRA, significantly increased the population of AGS and MKN-74 cells in the subG1 phase and decreased the $\mathrm{Bcl}-2 / \mathrm{Bax}$ ratio $(\mathrm{P}<0.05)$. Furthermore, in MNK-74 and SC-M1 cells treated with 12-O-tetradecanoylphorbol-13-
\end{abstract}

Correspondence to: Dr Kong-Wang Hu, Department of General Surgery, The First Hospital of Anhui Medical University, 218 Jixi Road, Hefei, Anhui 230022, P.R. China

E-mail:hukw@sina.com

Abbreviations: ATPR, 4-amino-2-trifluoromethyl-phenyl retinate; ATRA, all-trans retinoic acid; RA, retinoic acid; RAR- $\alpha$, retinoic acid receptor- $\alpha$; RXR- $\alpha$, retinoid $\mathrm{X}$ receptor- $\alpha$; RARE, RA response elements; AP-1, activator protein-1; TPA, 12-O-tetradecanoylphorbol13-acetate;

Key words: gastric cancer, all-trans retinoic acid, activator protein-1, retinoid X receptor- $\alpha$, cyclin $\mathrm{E}, \mathrm{Bax}$ acetate (TPA) and 5 or $10 \mu \mathrm{M}$ of ATPR significantly suppressed the activity of the AP-1 reporter as compared to treatment with ATRA $(\mathrm{P}<0.05)$. Thus, ATPR inhibits cancer cell proliferation to a greater extent compared to ATRA, possibly through the RXR-mediated inhibition of AP-1 activity.

\section{Introduction}

Retinoic acid (RA), a metabolite of vitamin A, influences cell growth, differentiation and apoptosis in adult tissues, as well as during embryonic development $(1,2)$. RA signaling is mediated through binding to members of the RA receptor (RAR) family, includingRAR- $\alpha$ and retinoid Xreceptor- $\alpha(\mathrm{RXR}-\alpha)(1)$. Theseare nuclear receptors and as such, RAR-RXR heterodimers control the expression of target genes through interactions with RA response elements (RARE) and by recruiting coactivators to the promoter region of target genes (3).

In addition to altering cell cycle progression and inducing apoptosis, retinoids have also been shown to inhibit activator protein-1 (AP-1) signaling (4,5). AP-1 transcription factors, heterodimers that include members of the c-Fos and c-Jun families, are required for the development and progression of malignant tumors (6). Although it has been shown that the transactivation of RARE and the subsequent upregulation of RAR- $\alpha$ is involved in the inhibition of AP-1 activity (5), another study reported that retinoids inhibit AP-1 activity through transrepression (4).

Altered RA signaling, as a result of a chromosomal translocation resulting in a RAR- $\alpha$-promyelocytic leukemia (PML) gene fusion or abnormal RAR- $\alpha$ transcription, has been reported in a number of inflammatory and neoplastic diseases, including breast cancer and promyelocytic leukemia (7). RA analogs, including all-trans retinoic acid (ATRA) and its metabolite, 9-cis-RA (8), are thought influence cell cycle progression in a time-dependent manner (9); however, the involvement of p53 and p21waf may be cell type-dependent $(9,10)$. ATRA has been shown to inhibit the growth of gastric cancer cells by upregulating RAR- $\alpha$ expression (5).

RA analogs have been used in the treatment of a variety of cancers; however, a high rate of early mortality (11-13), serious therapy-related sequelae, including myelodysplastic syndrome and acute myeloid leukemia $(14,15)$, as well as a high incidence 
of side-effects (16) have been observed with this treatment. In addition, the tight metabolic control of ATRA (17) and of 9-cis RA (18) levels under normal physiological conditions may limit their use in anticancer therapeutics. Thus, the identification and characterization of novel RA analogs that inhibit cancer cell growth without the associated side-effects would be important for the clinical treatment of cancer. The aim of this study was to compare the effects of a novel RA analog, 4-amino-2-trifluoromethyl-phenyl retinate (ATPR) (19), with those of ATRA $(20,21)$ on the growth and distribution of gastric cancer cells in different cell cycle phases, using the AGS, MKN-74 and SC-M1 cell lines. Cyclin E, Bcl-2 and Bax expression, as well as AP-1 activity were also measured following treatment with ATPR and ATRA. ATPR inhibited cancer cell proliferation to a greater extent compared with ATRA, possibly through the RXR-mediated inhibition of AP-1 activity.

\section{Materials and methods}

Cell cultures. Three gastric cancer cell lines, AGS, MKN-74 and SC-M1, were purchased from the Institute of Cell Biology, Shanghai, China. Cells were maintained in RPMI-1640 medium (Invitrogen Life Technologies, Carlsbad, CA, USA) containing $10 \%$ fetal bovine serum (FBS; Invitrogen Life Technologies), streptomycin $(500 \mu \mathrm{g} / \mathrm{ml})$ and penicillin $(500 \mu \mathrm{g} / \mathrm{ml})$, in a $5 \% \mathrm{CO}_{2}$ atmosphere at $37^{\circ} \mathrm{C}$.

Receptor ligand binding assay. Binding affinity of ATPR, ATRA and 9-cis-RA (purchased from Sigma-Aldrich, St. Louis, MO, USA) to RAR- $\alpha$ and RXR- $\alpha$ was assessed by time-resolved fluorescence resonance energy transfer (TR-FRET) analysis using LanthaScreen ${ }^{\mathrm{TM}}$ TR-FRET RXR- $\alpha$ and RAR- $\alpha$ Coactivator Assay kits (catalog nos. PV4797 and PV4409, respectively; Invitrogen Life Technologies), following the manufacturer's instructions. In a cell-free system, the FRET signal reflects the binding of the ligand to the nuclear receptor and subsequent recruitment of coactivator peptides. Briefly, the following 11 serial dilutions of ATPR, ATRA and 9-cis-RA were prepared in RPMI-1640 medium from corresponding starting solutions $\left(10^{-3} \mathrm{M}\right)$ in dimethyl sulfoxide (DMSO): $1 \times 10^{-6}, 2 \times 10^{-7}, 4 \times 10^{-8}, 8 \times 10^{-9}, 1.6 \times 10^{-9}, 3.2 \times 10^{-10}$, $6.4 \times 10^{-11}, 1.28 \times 10^{-11}, 2.56 \times 10^{-12}, 5.12 \times 10^{-13}$ and $1.02 \times 10^{-13} \mathrm{M}$.

MTT assay. The SC-M1 and MKN-74 cells were seeded onto 96 -well plates $(200 \mu \mathrm{l} /$ well $)$ at a density of $2.5 \times 10^{4}$ cells $/ \mathrm{ml}$ and cultured for 9-12 h. The cells were then incubated in medium containing DMSO or 5, 10 and $500 \mu \mathrm{M}$ ATPR or ATRA for 3 or 6 days. In order to determine cell growth, cells were incubated with $20 \mu \mathrm{l} /$ well MTT solution $(5 \mathrm{mg} / \mathrm{ml}$; Sigma-Aldrich) for $4 \mathrm{~h}$ at $5 \% \mathrm{CO}_{2}$ and $37^{\circ} \mathrm{C}$. Following the removal of the medium, DMSO was added to each well (100 $\mu \mathrm{l} /$ well) and incubated for $5 \mathrm{~min}$ with continuous shaking. The optical density (OD) was detected at $540 \mathrm{~nm}$ with a SpectraMax 190 microplate reader (Molecular Devices, Sunnyvale, CA, USA). A $100 \%$ proliferation was assigned to DMSO-treated cells, and the suppressive effects of ATRA and ATPR $(5,10$ and $500 \mu \mathrm{M})$ on cell growth were determined. The MTT assay was performed in triplicate in 3 independent biological repetitions.
Cell cycle analysis. The AGS and MKN-74 cells ( $3 \times 10^{5}$ cells) were cultured in 6-well plates for $16 \mathrm{~h}$, and were treated with ATRA or ATPR (both at 10 and $50 \mu \mathrm{M}$ ). After $24 \mathrm{~h}$, the medium was removed to collect floating cells. The attached cells were trypsinized with $0.25 \%$ Trypsin/EDTA, pooled with the cells collected from the culture medium, and fixed with cold $\left(-20^{\circ} \mathrm{C}\right)$ ethanol overnight. The fixed cells were washed twice in phosphate-buffered saline (PBS) following centrifugation at $1,500 \mathrm{rpm}$ for $5 \mathrm{~min}$ and stained with a solution containing RNase A $(100 \mu \mathrm{g} / \mathrm{ml}), 20 \mu \mathrm{g} / \mathrm{ml}$ propidium iodide (PI) (both from Sigma-Aldrich) and 0.1\% Triton X-100 in PBS for 30 min. The cells were washed twice in PBS prior to analysis on a FACSCalibur flow cytometer (BD Biosciences, Franklin Lakes, NJ, USA). This experiment was performed at least 3 times independently.

Western blot analysis. MKN-74 cells were treated with ATPR $(10$ and $50 \mu \mathrm{M})$ as described above in the cell cycle analysis, and protein extracts were harvested by incubation in cell lysis buffer (SoluLyse-M Mammalian protein extraction reagent; Genlantis, San Diego, CA, USA) in the presence of protease inhibitors (ProBlock Gold Mammalian; Gold Biotechnology, Inc., St. Louis, MO, USA) on ice for $10 \mathrm{~min}$. Chromosomal DNA was fragmented by ultrasonication. Protein concentration was determined using the Bradford protein assay (Bio-Rad, Hercules, CA, USA). Proteins (10 $\mu \mathrm{g}$ ) were separated using SDS-PAGE and transferred onto a nitrocellulose membrane. After non-specific binding was blocked by incubation for $60 \mathrm{~min}$ in PBS with Tween 20 (PBST) buffer supplemented with 5\% skim milk, the membrane was incubated with the following primary antibodies: anti-cyclin E (Invitrogen Life Technologies), antiBcl-2 and anti-Bax (both from Epitomics, Burlingame, CA, USA) in the concentrations suggested by the corresponding manufacturers. The expression of $\beta$-actin, serving as the loading control, was assessed using an anti- $\beta$-actin antibody (Millipore, Billerica, MA, USA). The membrane was developed in ECL reagent (Millipore) and visualized using a CCD camera (Fusion FX7; Vilber Lourmat, Eberhardzell, Germany). Following autoradiography, data from the films were analyzed using GelQuant. NET software (available at www.biochemlabsolutions.com).

Analysis of AP-1 activity. The MKN-74 and SC-M1 cells $\left(4 \times 10^{4}\right.$ cells) cultured in 96-well plates were transfected using Attractene transfection reagent (Qiagen, Hilden, Germany) following the manufacturer's instructions. Briefly, the reagent was mixed with either the Cignal AP-1 reporter (SABiosciences, Germany) or the control reporters, TATA (negative control) and CMV (positive control), along with the Renilla luciferase reporter (Promega, Fitchburg, WI, USA) and the mixture was incubated at room temperature for $20 \mathrm{~min}$. Following incubation of the cells with the transfection mixture for $16 \mathrm{~h}$, selected cell groups were further treated with phorbol ester $12-O$-tetradecanoylphorbol-13-acetate (TPA, $100 \mathrm{ng} / \mathrm{ml}$; Sigma-Aldrich) for $6 \mathrm{~h}$. All cells were then treated with 5,10 or $500 \mu \mathrm{M}$ ATRA or ATPR for $24 \mathrm{~h}$. After the cells were washed twice with PBS, they were incubated in passive lysis buffer for 15 min with continuous shaking, and the luciferase assay reagent II was added. Firefly luciferase activity was determined with a SpectraMax 190 microplate luminometer (Molecular Devices). The Stop \& Glo reagent (Promega) was then added 
to measure the Renilla luciferase activity, as an internal control for the transfection activity assay. The reporter activity was determined by normalizing the values obtained for the firefly luciferase activity to those obtained for the Renilla luciferase reporter activity. The experiment was performed 3 times.

Statistical analyses. Normally-distributed continuous variables were compared by a one-way analysis of variance (ANOVA). When a significant difference between groups was observed, comparisons of means were performed using the Bonferroni type I error adjustment. Data are presented as the means \pm SD. All statistical assessments are derived from two-sided tests, with a P-value of 0.05 considered to indicate a statistically significant difference. Statistical analyses were performed using SPSS 15.0 software (SPSS Inc., Chicago, IL, USA).

\section{Results}

Determination of the binding affinity of ATPR to RARs. As the receptor mediating the effects of ATPR remains unknown, ligand binding assays were undertaken to examine the binding affinity of ATPR to 2 RARs, RAR- $\alpha$ and RXR- $\alpha$. The binding affinities of 2 well-known RA analogs, 9-cis-RA and ATRA, were used as the positive controls. 9-cis-RA bound to both receptors with high affinity $(0.34 \mathrm{nM}$ to RAR- $\alpha$ and $0.37 \mathrm{nM}$ to RXR- $\alpha$ ) (Fig. 1A and B). ATRA preferentially bound to RAR- $\alpha(0.23 \mathrm{nM})$ (Fig. 1C) as compared to RXR- $\alpha(19 \mathrm{nM})$ (Fig. 1D). Furthermore, ATPR preferentially bound to RXR- $\alpha$ (0.04 nM) (Fig. 1F) as compared to RAR- $\alpha$ (20.96 nM) (Fig. 1E).

Suppression of gastric cancer cell growth by ATPR. To determine whether ATPR suppresses cancer cell proliferation, 3 gastric cancer cell lines, AGS, MKN-74 and SC-M1, were cultured in the presence of 5,10 or $500 \mu \mathrm{M}$ ATPR, ATRA or DMSO (vehicle control) for 3 or 6 days. As illustrated in Fig. 2, ATRA and ATPR inhibited growth of AGS, MKN-74 and SC-M1 cells in a dose-dependent manner. At 3 days, ATPR induced a significantly greater inhibitory effect on cell growth compared to ATRA, with the exception of the $10 \mu \mathrm{M}$-treated AGS cells, in which both ATPR and ATRA exerted comparable inhibitory effects (all $\mathrm{P}<0.05)$ (Fig. 2A). At 6 days, a greater cell growth inhibitory effect was only observed in the MKN-74 cells treated with 5 and $10 \mu \mathrm{M}$ ATPR and in the SC-M1 cells treated with $500 \mu \mathrm{M}$ ATRA $(\mathrm{P}<0.05)$ (Fig. 2B and C).

Alteration of cell cycle progression by ATPR. To determine whether ATRA or ATPR alters the cell cycel progression, the AGS and MKN-74 cells were treated with 10 or $50 \mu \mathrm{M}$ ATRA or ATPR for $24 \mathrm{~h}$ prior to PI staining and flow cytometric analysis. Whereas ATRA did not significantly alter the cell cycle distribution of the AGS and MKN-74 cells (Fig. 3A and B, respectively), $50 \mu \mathrm{M}$ ATPR significantly increased the population of AGS and MKN-74 cells at the subG1 phase, suggesting the induction of apoptosis in this treatment group (both $\mathrm{P}<0.05)$. Furthermore, $50 \mu \mathrm{M}$ ATPR significantly reduced the percentage of cells at the G0/G1 and G2/M phases in both cell lines (both $\mathrm{P}<0.05$ ).
Effects of ATPR on apoptosis-related protein expression in $M K N-74$ cells. To evaluate the hypothesis that ATPR induces apoptosis in MKN-74 cells, the expression of the apoptosis-related proteins, cyclin E, Bcl-2 and Bax, in response to 10 and $50 \mu \mathrm{M}$ ATPR treatment was assessed by western blot analysis. The treatment of MKN-74 cells with $50 \mu \mathrm{M}$ ATPR reduced the cyclin E level and upregulated Bax expression compared with the DMSO-treated group (Fig. 4A). The Bcl-2/ Bax ratio was significantly reduced following treatment with $50 \mu \mathrm{M}$ ATPR as compared with the DMSO-treated group $(\mathrm{P}<0.05)$ (Fig. 4B); however, this effect was not observed with $10 \mu \mathrm{M}$ ATPR.

Suppressive effects of ATPR on AP-1 reporter activity. As a number of RA analogs suppress tumor growth through the inhibition of AP-1 activity (4,5), the effects of ATPR on AP-1 activity in MNK-74 and SC-M1 cells were determined using a reporter gene construct with tandem repeats of the AP-1 binding site upstream of the firefly luciferase gene.

Compared with the reporter activities of the TATA and CMV groups, the basal and TPA-induced AP-1 reporter activities were relatively higher in the MNK-74 cells (Fig. 5A). Furthermore, the treatment of MKN74 cells with TPA for $24 \mathrm{~h}$ significantly increased the AP-1 reporter activity as compared with the corresponding non-TPA-treated group $(\mathrm{P}<0.05)$ (Fig. 5A). Comparable effects on the AP-1 reporter activity were observed upon treatment with various concentrations of ATPR and ATRA in the absence of TPA (Fig. 5B). However, in the presence of TPA, both 5 and $10 \mu \mathrm{M}$ ATPR significantly suppressed AP-1 reporter activity as compared with ATRA (Fig. 5C).

In the SC-M1 cells, the basal AP-1 reporter activity appeared similar to that of the CMV group, and TPA failed to significantly increase it (Fig. 6A). In the absence of TPA, 5 or $10 \mu \mathrm{M}$ ATRA significantly enhanced the AP-1 reporter activity compared with the corresponding DMSO-treated group (Fig. 6B). Although $10 \mu \mathrm{M}$ ATPR significantly reduced the AP-1 reporter activity as compared with the same concentration of ATRA, the reduced AP-1 activity was comparable to that observed in the corresponding DMSOtreated group (Fig. 6B). In the presence of TPA, 5 or $10 \mu \mathrm{M}$ ATRA significantly enhanced the AP-1 reporter activity (Fig. 6C). Although 5 and $10 \mu \mathrm{M}$ ATPR reduced AP-1 reporter activity as compared with the corresponding ATRA-treated groups, the reduction was again comparable to that observed in the corresponding DMSO-treated group (Fig. 6C).

\section{Discussion}

The effect of a novel RA analog, ATPR, on gastric cancer cell growth was evaluated in the present study. At 3 days, ATPR inhibited the growth of MKN-74 and SC-M1 cells to a greater extent compared with ATRA. ATPR further significantly increased the population of cells at the subG1 phase and reduced the percentage of cells at the G0/G1 and $\mathrm{G} 2 / \mathrm{M}$ phases. The MKN-74 cells treated with $50 \mu \mathrm{M}$ ATPR showed a reduction in cyclin $\mathrm{E}$ levels and an increased Bax protein expression. A reduction in TPA-induced AP-1 activity was also observed in the cells treated with ATPR. 

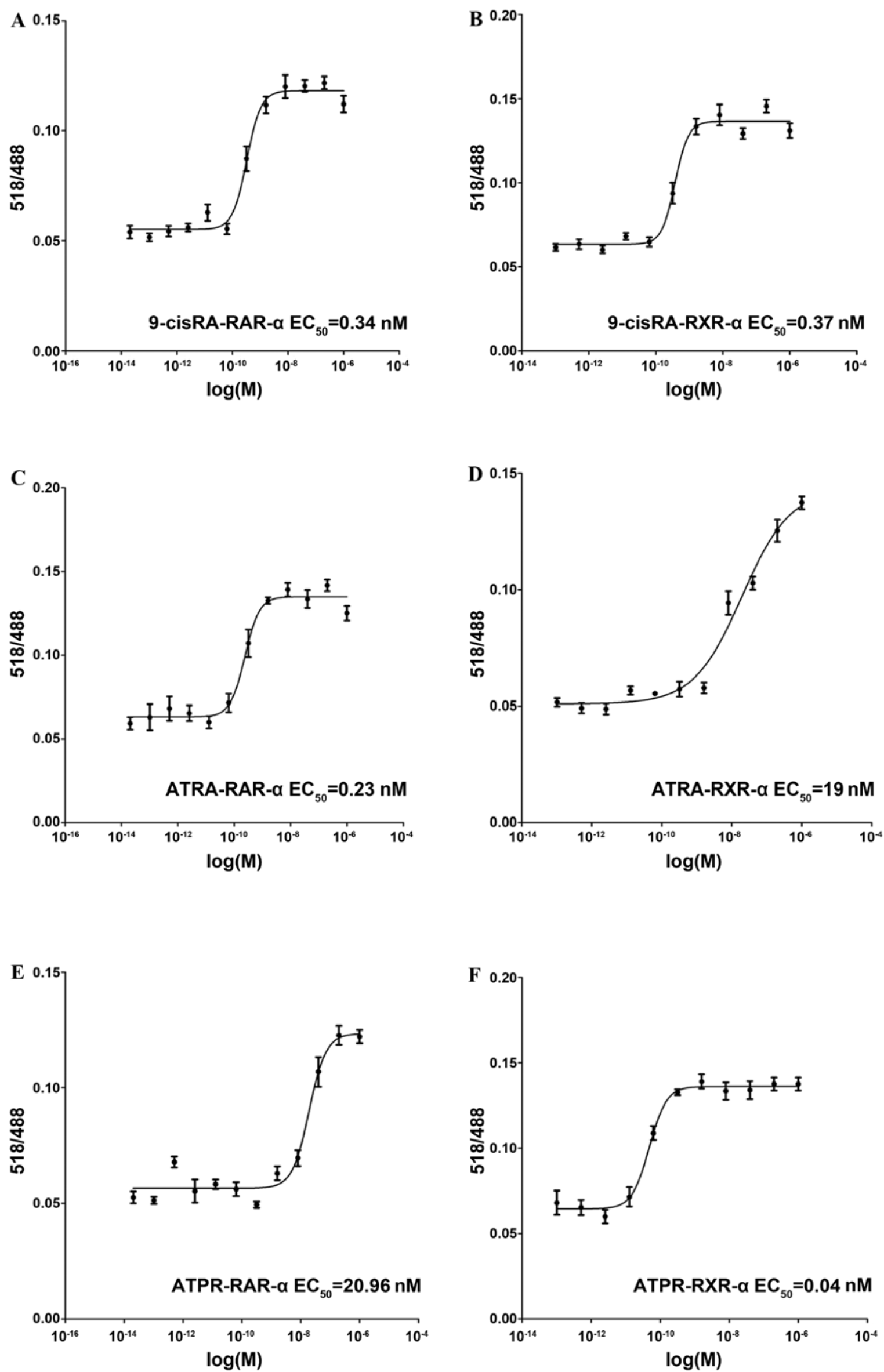

Figure 1. Binding of retinoic acid (RA) analogs to retinoic acid receptors. (A and B) 9-cis-retinoic acid (9-cis-RA), (C and D) all-trans retinoic acid (ATRA) and (E and F) 4-amino-2-trifluoromethyl-phenyl retinate (ATPR) binding affinity to (A, C and E) retinoic acid receptor- $\alpha$ (RAR- $\alpha$ ) and (B, D and F) retinoid X receptor- $\alpha(\mathrm{RXR}-\alpha)$ was assessed using ligand binding assays, from which $\mathrm{EC}_{50}$ values were calculated. 
A AGS

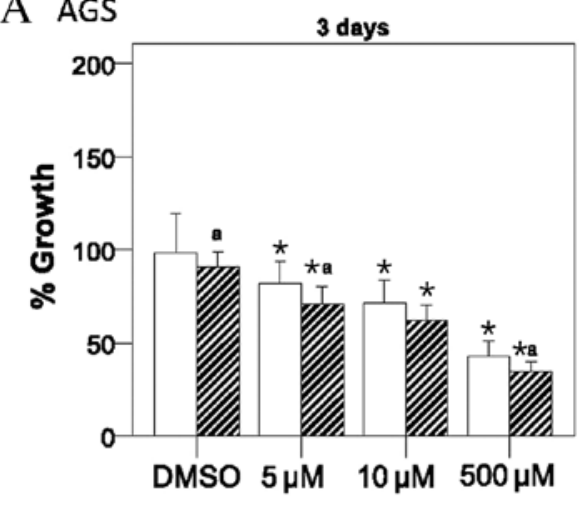

B MKN-74

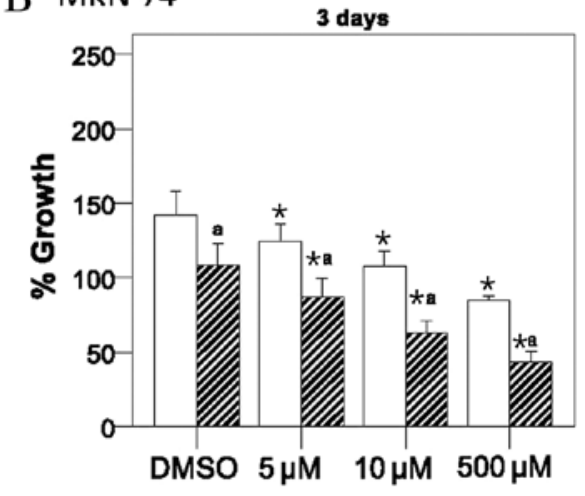

C SC-M1

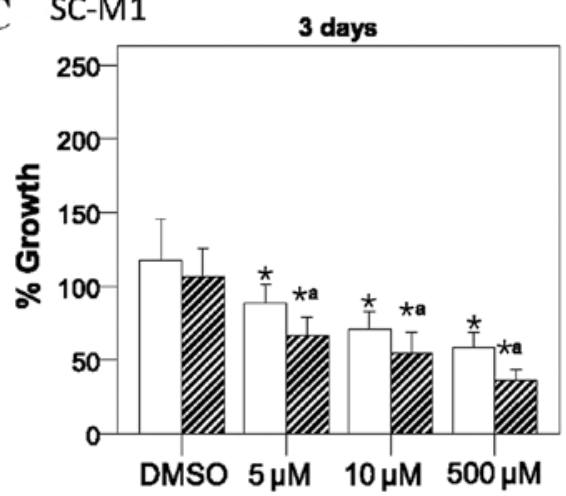

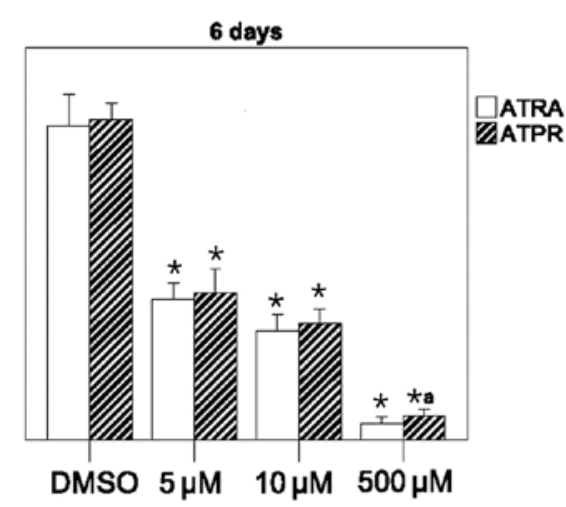
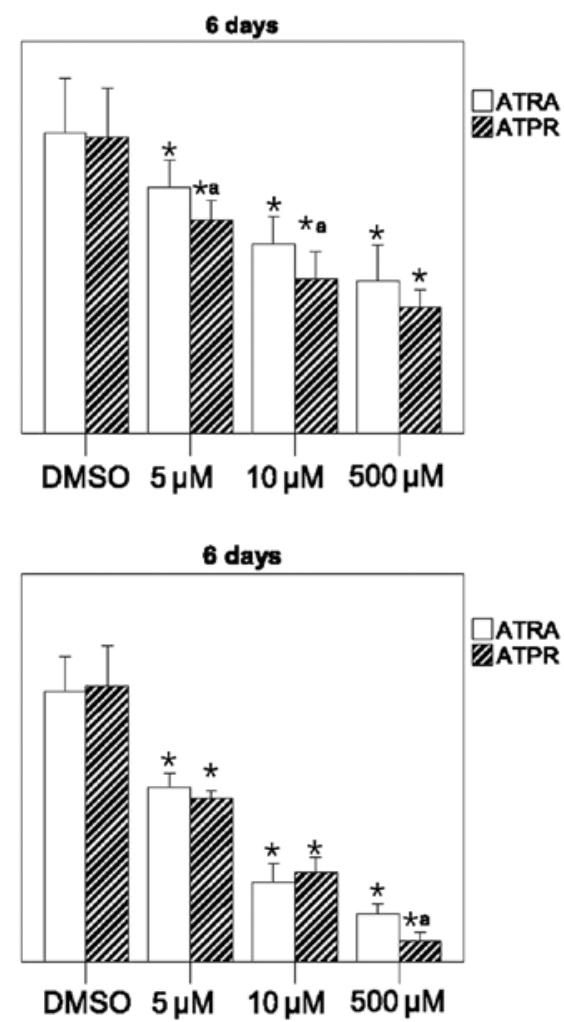

Figure 2. Effects of 4-amino-2-trifluoromethyl-phenyl retinate (ATPR) on gastric cancer cell growth. MTT assay was used to evaluate the effects of ATPR (5, 10 and $500 \mu \mathrm{M}$ ) on (A) AGS, (B) MKN-74 and (C) SC-M1 cell growth. Cells were treated with ATPR for 3 (left panels) or 6 days (right panels) prior to the MTT assay. Dimethyl sulfoxide (DMSO) and all-trans retinoic acid (ATRA) $(5,10$ and $500 \mu \mathrm{M})$ were used as the controls. The values were normalized to those obtained from the untreated control cells after 3 days. ${ }^{~} \mathrm{P}<0.05$ vs. the DMSO (vehicle control) of the same (ATRA- or ATPR-treated) group; ${ }^{\text {a }}<0.05$ vs. the group treated with the same ATRA concentration.

As opposed to 9-cis-RA that bound to both RAR- $\alpha$ and RXR- $\alpha$ with high affinity, and ATRA that preferentially bound to RAR- $\alpha$, binding assays revealed that ATPR preferentially binds RXR- $\alpha$. As previously described, the effects of retinoids can be mediated by either RAR-RXR heterodimers or RXR-RXR homodimers $(3,22)$. The effects of a set of novel selective RA analogs were examined by Kizaki et al (22); ligands that specifically activated RAR/RXR heterodimers not only inhibited growth, but also induced the differentiation of human leukemic cells, as opposed to analogs that activated RXR homodimers alone (22). In human glioblastoma cell lines, the inhibition of cell proliferation was observed upon ATRA treatment, highlighting the importance of RAR activation in these cells (23). Further studies are required to determine whether ATPR-bound RXR- $\alpha$ reduces gastric cancer cell growth and inhibits AP-1 activity through the induction of RXR homodimerization and subsequent transrepression or through heterodimerization with RAR, followed by RARE transactivation.

In the present study, ATPR inhibited gastric cancer cell growth to a greater extent compared with ATRA. The anti-proliferative effects of ATPR are consistent with those reported in previous in vivo and in vitro studies (24). ATPR reduced the cyclin E level in MKN-74 cells, and altered cell cycle progression in the AGS and MKN-74 cells; however, no such effects were observed following treatment with ATRA. Wu et al (25) observed differences in cell cycle progression upon treatment with ATRA in BGC-823 gastric 
A AGS

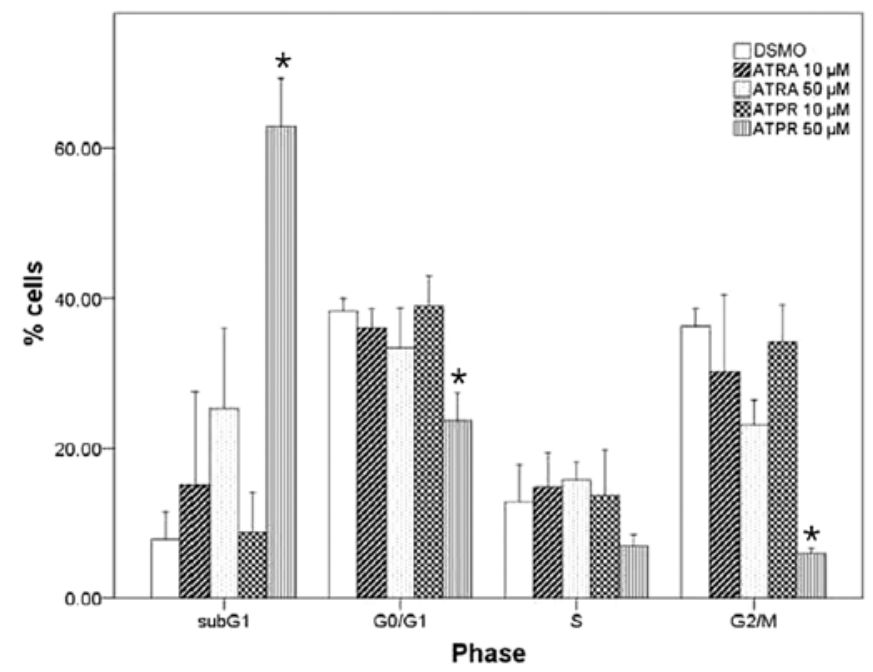

B MKN-74

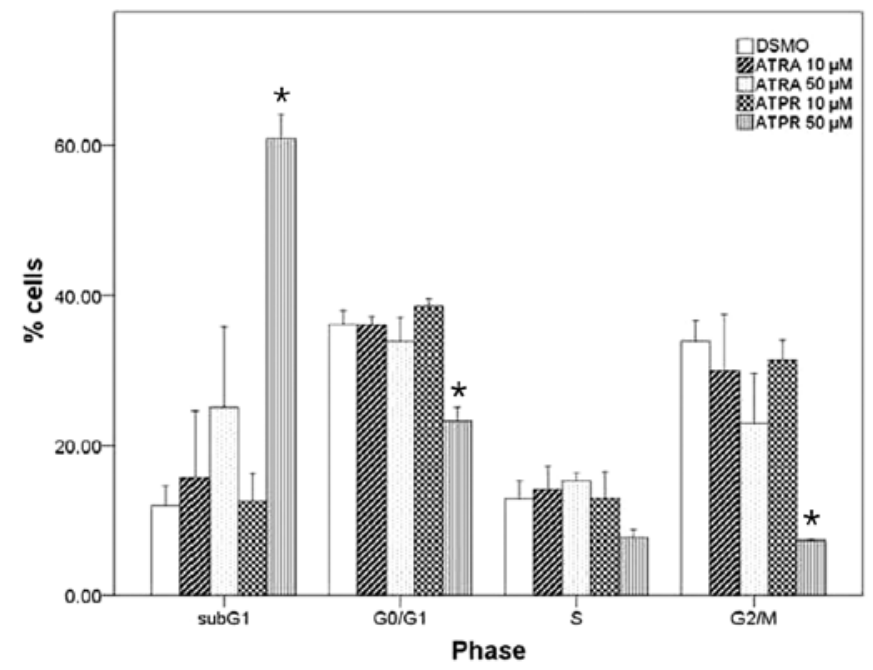

Figure 3. Alteration of cell cycle progression by 4-amino-2-trifluoromethylphenyl retinate (ATPR). (A) AGS and (B) MKN-74 cells were treated with 10 or $50 \mu \mathrm{M}$ all-trans retinoic acid (ATRA) or ATPR for $24 \mathrm{~h}$ prior to propidium iodide (PI) staining and flow cytometric analysis. ${ }^{~} \mathrm{P}<0.05$ vs. the corresponding dimethyl sulfoxide (DMSO) group.

cancer cells. We speculate that this difference in results between the studies is due to differences in the examined cell types (differential RAR expression), as well as in the concentration of ATRA used. In vivo analyses revealed that ATRA inhibited the growth and metastasis of gastric cancer cell xenografts, as well as the expression of proteins associated with metastasis, including nm23, mts1/p16 and ICAM-1 (25). Furthermore, reduced microvessel formation was observed with ATRA treatment (25), which may be related to inhibition, by ATRA, of the mRNA and protein expression of the vascular endothelial growth factor, observed in gastric cancer cells (26).

AP-1 transactivation is associated with cell growth, proliferation and survival, and the transrepression of its activity in the
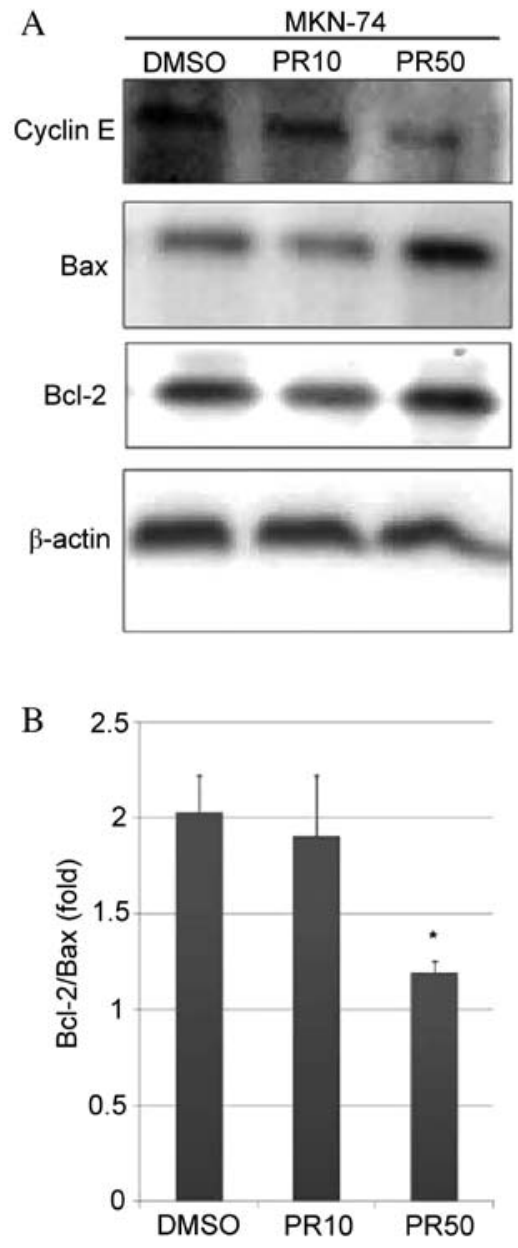

Figure 4. Effects of 4-amino-2-trifluoromethyl-phenyl retinate (ATPR) on the expression of apoptosis-related proteins in MKN-74 cells. The cells were treated with dimethyl sulfoxide (DMSO) control (lane 1), $10 \mu \mathrm{M}$ ATPR (lane 2; PR10) and $50 \mu \mathrm{M}$ ATPR (lane 3; PR50) for $24 \mathrm{~h}$. $\beta$-actin was used as the loading control. (A) Representative blot from 3 independent experiments. (B) Bcl-2/Bax expression ratios (fold) from quantification of the western blot analysis results. ${ }^{*} \mathrm{P}<0.05$ vs. the DMSO group.

absence of RARE transactivation is a well-characterized anticancer retinoid effect $(4,27,28)$. In the present study, both ATPR and ATRA inhibited basal and TPA-induced AP-1 activity, in agreement with previous reports on BGC-823 gastric cancer cells (29). However, this effect was not observed in the MKN-45 cells, which are negative for RAR- $\beta$ expression, suggesting that RAR- $\beta$ may act as the mediator of retinoid-induced AP-1 transrepression (29). Alternatively, in the SC-M1 cells, lower concentrations of ATRA actually increased AP-1 activity.

In the present study, ATPR altered cell cycle progression by inducing apoptosis (i.e., increased the population of cells at the subG1 phase). Quantification of the levels of the apoptosis-related proteins, Bax and $\mathrm{Bcl}-2$, indicated that ATPR reduced the Bcl-2/Bax ratio. However, no such effects were observed following treatment with ATRA (data not shown). Bcl-2 promotes cell survival and is overexpressed in many tumor types (30), and its inhibition by small molecules may be beneficial for cancer treatment $(30,31)$. The reduced $\mathrm{Bcl}-2 / \mathrm{Bax}$ ratio is associated with the activation of caspase- 3 and subsequent apoptosis $(32,33)$. In our study, in addition to the reduced Bcl-2/Bax ratio, a lower cyclin E level was observed 

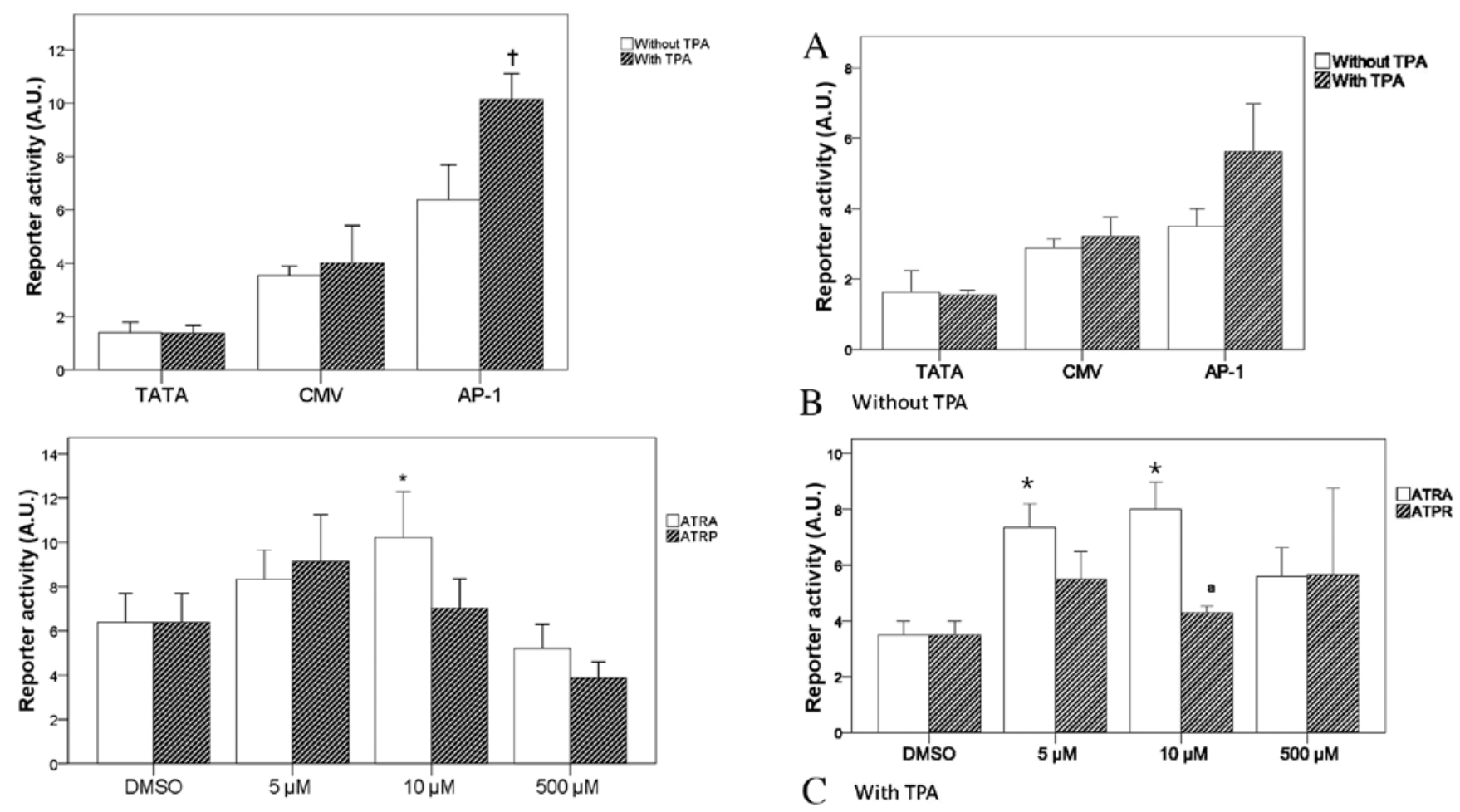

C With TPA
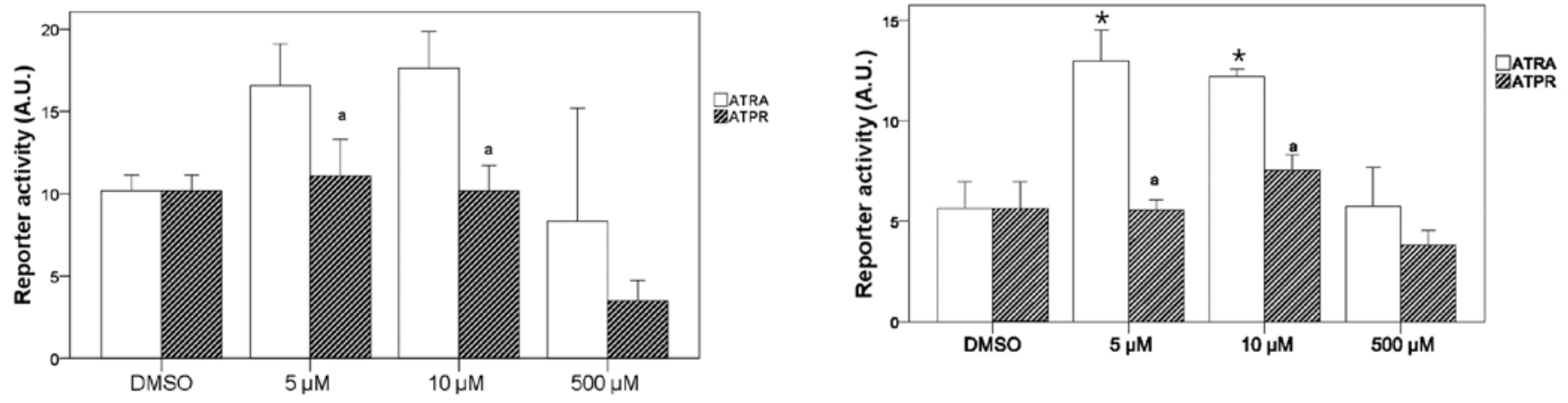

Figure 5. Effects of 4-amino-2-trifluoromethyl-phenyl retinate (ATPR) on activator protein-1 (AP-1) reporter activity in MNK-74 cells. AP-1 activity was determined using a reporter gene construct with tandem repeats of the AP-1 binding site upstream of the firefly luciferase gene. (A) Effect of 12- $O$-tetradecanoylphorbol-13-acetate (TPA) on AP-1 reporter activity. TATA and $\mathrm{CMV}$ were used as thenegative and positivecontrols, respectively.(B)Effects of 5, 10 and $500 \mu \mathrm{M}$ ATPR on AP-1 reporter activity in the absence of TPA and (C) in the presence of TPA. ${ }^{\dagger} \mathrm{P}<0.05$ vs.the correspondingnon-TPA-treatedgroup; ${ }^{*} \mathrm{P}<0.05$ vs. the corresponding dimethyl sulfoxide (DMSO) group; ${ }^{\mathrm{a}} \mathrm{P}<0.05$ vs. the all-trans retinoic acid (ATRA) group, treated with the same concentration.

upon treatment with $50 \mu \mathrm{M}$ ATPR. The cyclin E level not only reflects the proliferative state of cells, but may also determine the extent of apoptosis (34). Specifically, p18-cyclin E, which results from the N-terminal truncation of cyclin $\mathrm{E}$ in tumor cells, can induce apoptosis independently of Cdk2 (34). Further studies are required to assess whether the reduced cyclin E level following ATPR treatment results in a concomitant increase in the p18-cyclin E level. Although the present study did not directly assess the effects of ATPR on apoptosis (which will be the subject of a future study e.g., by TUNEL assay), its effects on cell cycle progression and on the $\mathrm{Bcl}-2 / \mathrm{Bax}$ ratio suggest that it induces the apoptosis of gastric cancer cells.

In addition to influencing cell growth and apoptosis, RA analogs, including ATPR, can induce cell differentiation in embryonic and adult tissues $(1,2,24)$. Similarly, RA and a number of its analogs inhibit tumor progression by inducing cell differentiation (16), possibly through phosphatidylinositol 3-kinase (PI3K) signaling (35). Although the present study did not analyze the effects of ATPR on gastric cancer cell differentiation, this will be analyzed in future studies using an in vivo model of gastric cancer. The effects of ATPR on tumor formation and morphology will also be assessed using in vivo tumor xenografts.

In conclusion, we demonstrate that ATPR inhibits cancer cell proliferation, induces cell cycle arrest and inhibits the activity of AP-1 to a greater extent compared with ATRA. These data form the basis of future analyses aiming to determine its efficacy in vivo. 


\section{Acknowledgements}

The present study was supported by the following grants: National ‘Major Drug Discovery’ Major Science and Technology Funding of China (no. 2011ZX09401-021); Natural Science Foundation of the Department of Education, Anhui Province (no. KJ2010A171); Natural Science Foundation of the Bureau of Health, Anhui Province (no. 09C157).

\section{References}

1. Campo-Paysaa F, Marlétaz F, Laudet V and Schubert M: Retinoic acid signaling in development: tissue-specific functions and evolutionary origins. Genesis 46: 640-656, 2008.

2. Mark M, Ghyselinck NB and Chambon P: Function of retinoic acid receptors during embryonic development. Nucl Recept Signal 7: e002, 2009.

3. McKenna NJ and O'Malley BW: Combinatorial control of gene expression by nuclear receptors and coregulators. Cell 108: 465-474, 2002.

4. Li JJ, Dong Z, Dawson MI and Colburn NH: Inhibition of tumor promoter-induced transformation by retinoids that transrepress AP-1 without transactivating retinoic acid response element. Cancer Res 56: 483-489, 1996.

5. Liu S, Wu Q, Chen ZM and Su WJ: The effect pathway of retinoic acid through regulation of retinoic acid receptor alpha in gastric cancer cells. World J Gastroenterol 7: 662-666, 2001.

6. Sundqvist A, Zieba A, Vasilaki E, Herrera Hidalgo C, Söderberg O, Koinuma D, Miyazono K, Heldin CH, Landegren U, Ten Dijke P and van Dam H: Specific interactions between Smad proteins and AP-1 components determine TGF $\beta$-induced breast cancer cell invasion. Oncogene 32: 3606-3615, 2013.

7. McKenna NJ: EMBO Retinoids 2011: Mechanisms, biology and pathology of signaling by retinoic acid and retinoic acid receptors. Nucl Recept Signal 10: e003, 2012.

8. Kilewer SA, Umesono K, Noonan DJ, Heyman RA and Evans RM: Covergence of 9-cis retinoic acid and peroxisome proliferator signaling pathways through heterodimer formation of their receptors. Nature 358: 771-774, 1992.

9. Dierov J, Sawaya BE, Prosniak M and Gartenhaus RB: Retinoic acid modulates a bimodal effect on cell cycle progression in human adult T-cell leukemia cells. Clin Cancer Res 5: 2540-2547, 1999.

10. Tillmanns TD, Kamelle SA, Guruswamy S, Gould NS, Rutledge TL and Benbrook DM: Sensitization of cervical cancer cell lines to low-dose radiation by retinoic acid does not require functional p53. Gynecol Oncol 97: 142-150, 2005.

11. Lehmann S, Ravn A, Carlsson L, Antunovic P, Deneberg S, Möllgård L, Derolf AR, Stockelberg D, Tidefelt U, Wahlin A, Wennström L, Höglund M and Juliusson G: Continuing high early death rate in acute promyelocytic leukemia: a populationbased report from the Swedish Adult Acute Leukemia Registry. Leukemia 25: 1128-1134, 2011.

12. Pagoni M, Garofalaki M, Panitsas F, Manola K, Psarra K, Economopoulos P, Vourtsi A, Antoniades M, Gkirkas K, Tzouvara E, Katis F, Prokopiou C, Tziotziou I, Balta A, Lemissiou E, Tsirigotis P, Repoussis P and Harhalakis N: Acute promyelocytic leukemia: an experience on 95 greek patients treated in the all-trans-retinoic acid era. Mediterr J Hematol Infect Dis 3: e2011053, 2011.

13. Park JH, Qiao B, Panageas KS, Schymura MJ, Jurcic JG, Rosenblat TL, Altman JK, Douer D, Rowe JM and Tallman MS: Early death rate in acute promyelocytic leukemia remains high despite all-trans retinoic acid. Blood 118: 1248-1254, 2011.

14. Latagliata R, Petti MC, Fenu S, Mancini M, Spiriti MA, Breccia M, Brunetti GA, Avvisati G, Lo Coco F and Mandelli F: Therapy-related myelodysplastic syndrome-acute myelogenous leukaemia in patients treated for acute promyelocytic leukaemia: an emerging problem. Blood 99: 822-824, 2002.

15. Zompi S and Viguie F: Therapy-related acute myeloid leukaemia and myelodysplasia after successful treatment of acute promyelocytic leukaemia. Leuk Lymphoma 43: 275-280, 2002.
16. Simoni D, Rondanin R, Baruchello R, Roberti M, Rossi M, Grimaudo S, D'Alessandro N, Invidiata FP and Tolomeo M: Retinoic acid and analogs as potent inducers of differentiation and apoptosis. New promising chemopreventive and chemotherapeutic agents in oncology. Pure Appl Chem 73: 1437-1444, 2001.

17. Adamson PC: All-trans-retinoic acid pharmacology and its impact on the treatment of acute promyelocytic leukemia. Oncologist 1: 305-314, 1996.

18. Allenby G, Bocquel MT, Saunders M, Kazmer S, Speck J, Rosenberger M, Lovey A, Kastner P, Grippo JF, Chambon P and Levin AA: Retinoic acid receptors and retinoid $X$ receptors interactions with endogenous retinoic acids. Proc Natl Acad Sci USA 90: 30-34, 1993.

19. Tang J, Yao J, Shi J, Xiao Q, Zhou J and Chen F: Synthesis, characterization, drug-loading capacity and safety of novel $\mathrm{pH}$-independent amphiphilic amino acid copolymer micelles. Pharmazie 67: 756-764, 2012.

20. Ahn HK, Jang J, Lee J, Se Hoon P, Park JO, Park YS, Lim HY, Kim KM and Kang WK: P21-activated kinase 4 overexpression in metastatic gastric cancer patients. Transl Oncol 4: 345-349, 2011.

21. Li CJ, Chu CY, Huang LH, Wang MH, Sheu LF, Yeh JI and Hsu HY: Synergistic anticancer activity of triptolide combined with cisplatin enhances apoptosis in gastric cancer in vitro and in vivo. Cancer Lett 319: 203-213, 2012.

22. Kizaki M, Dawson MI, Heyman R, Elster E, Morosetti R, Pakkala S, Chen DL, Ueno H, Chao W, Morikawa M, Ikeda Y, Heber D, Pfahl M and Koeffler HP: Effects of novel retinoid X receptor-selective ligands on myeloid leukemia differentiation and proliferation in vitro. Blood 87: 1977-1984, 1996.

23. Zang C, Wächter M, Liu H, Posch MG, Fenner MH, Stadelmann C, von Deimling A, Possinger K, Black KL, Koeffler HP and Elstner E: Ligands for PPARgamma and RAR cause induction of growth inhibition and apoptosis in human glioblastomas. J Neurooncol 65: 107-118, 2003.

24. Wang N, Ge JF, Pan CX, Peng XQ, Chen HH, Wang XQ, Tang J, Hu W and Chen FH: Anti-tumor effect of 4-Amino-2Trifluoromethyl-Phenyl Retinate on human breast cancer MCF-7 cells via up-regulation of retinoid receptor-induced gene-1. Biomed Pharmacother 67: 687-692, 2013.

25. Wu Q, Chen YQ, Chen ZM, Chen F and Su WJ: Effects of retinoic acid on metastasis and its related proteins in gastric cancer cells in vivo and in vitro. Acta Pharmacol Sin 23: 835-841, 2002.

26. Zhang JP, Chen XY and Li JS: Effects of all-trans-retinoic on human gastric cancer cells BGC-823. J Dig Dis 8: 29-34, 2007.

27. Agadir A, Shealy YF, Hill DL and Zhang X: Retinyl methyl ether down-regulates activator protein 1 transcriptional activation in breast cancer cells. Cancer Res 57: 3444-3450, 1997.

28. Wan H, Dawson MI, Hong WK and Lotan R: Enhancement of Calu-1 human lung carcinoma cell growth in serum-free medium by retinoids: dependence on AP-1 activation, but not on retinoid response element activation. Oncogene 15: 2109-2118, 1997.

29. Wu Q, Chen ZM and Su WJ: Anticancer effect of retinoic acid via AP-1 activity repression is mediated by retinoic acid receptor alpha and beta in gastric cancer cells. Int J Biochem Cell Biol 34: 1102-1114, 2002.

30. Cory S and Adams JM: Killing cancer cells by flipping the Bcl-2/Bax switch. Cancer Cell 8: 5-6, 2005.

31. Reed JC: Proapoptotic multidomain Bcl-2/Bax-family proteins: mechanisms, physiological roles, and therapeutic opportunities. Cell Death Differen 13: 1378-1386, 2006.

32. Tacar O, Sriamornsak P and Dass CR: Doxorubicin: an update on anticancer molecular action, toxicity and novel drug delivery systems. J Pharm Pharmacol 65: 157-170, 2013.

33. Albano F, Arcucci A, Granato G, Romano S, Montagnani S, De Vendittis E and Ruocco MR: Markers of mitochondrial dysfunction during the diclofenac-induced apoptosis in melanoma cell lines. Biochimie 95: 934-945, 2013.

34. Mazumder S, Plesca D and Almasan A: A jekyll and hyde role of cyclin $\mathrm{E}$ in the genotoxic stress response: switching from cell cycle control to apoptosis regulation. Cell Cycle 6: 1437-1442, 2007.

35. López-Carballo G, Moreno L, Masiá S, Pérez P and Barettino D: Activation of the phosphatidylinositol 3-kinase/Akt signaling pathway by retinoic acid is required for neural differentiation of SH-SY5Y human neuroblastoma cells. J Biol Chem 277: 25297-25304, 2002. 